\title{
Geoelectrical Investigation of a Proposed Landfill Site in Ogbomoso, Southwestern Nigeria
}

\author{
Ismaila. Abiodun Akinlabi* Adeniyi Abiodun Adewuyi \\ Department of Earth Sciences, Ladoke Akintola University of Technology, P.M.B. 4000, Ogbomoso
}

\begin{abstract}
An integrated geophysical investigation was carried out at a proposed landfill site along the new Ibadan-Ilorin Expressway in Ogbomoso, Southwestern Nigeria in order to characterize the subsurface and determine the suitability or otherwise of the site for landfill. The study location is underlain by rocks of the basement complex. 29 Schlumberger Vertical Electrical Soundings were conducted along seven traverses each about 100m long, about $20 \mathrm{~m}$ apart, with station spacing of about $30 \mathrm{~m}$ and half current electrode spacing varying between 1 and $100 \mathrm{~m}$. The VES data were interpreted quantitatively by partial curve matching and 1-D computer iteration and the layer parameters were used to generate the geoelectric sections. Wenner electrical resistivity profiling was also conducted along the traverses with station spacing of $25 \mathrm{~m}$ and electrode spacing varied between 5 and $15 \mathrm{~m}$, and the data were interpreted using 2D inversion procedures. The VES results revealed three layers defined by the topsoil, clay layer and fractured/fresh bedrock. Depth to the bedrock is generally shallow with a mean of $9.0 \pm$ $3.7 \mathrm{~m}$. The mean thickness of the saprolite (mainly comprising clay) is $8.6 \pm 4.0 \mathrm{~m} .2 \mathrm{D}$ inversion of the resistivity profiling data revealed intense fracturing of the bedrock. The water table is shallow, ranging from 2 to $6 \mathrm{~m}$ and may be rather close to the landfill base or fall within the landfill wastes. The study area is underlain by clayey overburden capable of protecting groundwater in the underlying aquifer unit from contamination by the leachate dischargeable from the landfill wastes. However, the presence of shallow water table and bedrock fractures may promote contamination of groundwater in the underlying aquifer unit and pose substantial health risk to the host community. It can therefore be concluded that the study area is not a suitable location for siting landfill.
\end{abstract}

Keywords: Contamination, Leachate, Clay, Water table, Bedrock fractures

DOI: $10.7176 /$ JEES/11-16-04

Publication date:June $30^{\text {th }} 2021$

\section{Introduction}

The amount of residential and industrial solid wastes, and the need for landfill sites, is ever growing due to increase in population and industrial production. A major source of groundwater pollution is the liquid generated within landfills, known as leachate, which is derived from liquids that acquire various contaminants as they percolate through the landfill waste (Scott et al., 2005; Schmoll, 2006). Since generation of wastes is inevitable, it is important to ensure that it is managed responsibly with proper regard to the environment. Landfill is a widely used method for environmentally safe disposal of solid wastes (Lema et al., 1988; Herma, 2003; Scott et al., 2005; AlJarrah and Abu-Qdais, 2006) and the selection of the most suitable site is a very crucial decision. It is an engineered method in which solid wastes are disposed of by spreading them in their layers, compacted to the smallest practical volume and covering them with earth daily or more frequently in a manner that will minimize environmental pollution (Scott et al., 2005).

The location of a landfill site requires a thorough understanding of the subsurface of the proposed site. Site investigation relying on boring and sampling techniques only provides point specific information and may thus be time consuming, labour intensive and expensive since many closely spaced exploratory boreholes may be required to reliably determine the characteristics of the subsurface materials at the site. Geophysical techniques are fast to use, and economical compared to other methods (Sharma, 1997) in selection of suitable landfill site. Geophysical surveys have been shown to be an efficient and cost effective complimentary technique to borehole drilling in engineering/geotechnical site investigation in areas underlain by crystalline basement complex and sedimentary rocks (Olorunfemi and Mesida, 1987; Olayinka and Oyedele, 2001; Ako et. al., 2006).

In view of aforementioned, a proposed landfill site was investigated in Ogbomoso, Southwestern Nigeria by using Schlumberger Vertical Electrical Sounding and Wenner Profiling techniques with a view to determining the subsurface stratification, nature and thickness of the overburden, depth to the bedrock, identify possible presence of fracture which may serve as conduits for leachate to flow into subsurface groundwater, and hence the suitability of the site for landfill.

The two geoelectrical techniques were combined for this study so that ambiguity arising from the interpretation results of one may be removed by consideration of results from the other (Steeples, 2001; Kearey et al., 2002). While the resistivity sounding technique detects vertical changes in resistivity by increasing the electrode separation systematically, the horizontal profiling technique detects lateral (horizontal) variations in resistivity and thus delineates vertical features such as fractures in the subsurface (Loke, 1999, Sharma, 1997) 
The study area is located along the Ogbomoso segment of the new Ibadan-Ilorin Expressway, within the geographic coordinates of Latitude $8^{\circ} 10.23^{\prime} \mathrm{N}$ to $8^{\circ} 10.34^{\prime} \mathrm{N}$ and Longitude $4^{\circ} 15.06^{\prime} \mathrm{E}$ to $4^{\circ} 15.15^{\prime} \mathrm{E}$ with approximate areal extent of $22,500 \mathrm{~m}^{2}$. The dominant rock types are migmatite gneiss and granite gneiss (Rahaman, 1988). Figure 1 shows the location of the study area.

\section{Methodology}

Twenty-nine VES stations, $25 \mathrm{~m}$ apart, were occupied along seven traverses, at about 20m interval, using the Schlumberger array with $\mathrm{AB} / 2$ varied between 1 and $133 \mathrm{~m}$. The resistivity data were acquired with ABEM Terrameter and its accessories to an error level less than $1 \%$.

The VES data were quantitatively interpreted using initial partial curve matching in which master curves and their corresponding auxiliary curves (Orellana and Mooney, 1966) were superimposed on the sounding curves to obtain the starting models i.e. layer parameters in terms of resistivities and thicknesses. The layer parameters were then used as input for computer-aided forward modeling technique (Zohdy, 1989) to determine the final models which were then used to generate the geoelectric sections.

Wenner profiling was carried out along the traverses to measure lateral variation of apparent resistivity. The electrode spacing ranged from $5 \mathrm{~m}$ to $15 \mathrm{~m}$. Data interpretation was carried out by using 2D inversion procedures which apply two-dimensional finite-difference algorithm (Dey and Morrison, 1979; Hohmann, 1982; Loke, 1999) to iteratively compute the resistivity response of a two dimensional model until a reasonable match is found between the theoretical and field pseudosections. Figure 2 shows the field layout of the VES stations and the profiles in the study area. Measurements were thereafter made in eleven hand-dug wells in the vicinity of the study area in order to determine the direction of groundwater flow.

\section{Results and Discussions}

The results of interpretation of the vertical electrical sounding data along the profiles are presented in the geoelectric sections shown in Figures 3 and 4. The study area is characterized by three geoelectric layers defined by topsoil, saprolite and bedrock. The topsoil has resistivity and thickness ranging from 29 to $1188 \Omega \mathrm{m}$ and 0.8 to $2.2 \mathrm{~m}$ respectively. The composition of the layer varies from clay to sandy clay. The thickness of the saprolite is $2.5-19.4 \mathrm{~m}$, with a mean of $8.6 \pm 4.0 \mathrm{~m}$ while its resistivity ranges from 21 to $162 \Omega \mathrm{m}$ suggestive of clay and sandy clay. The resistivity of the saprolite is less than $100 \Omega \mathrm{m}$ at most of the VES points reflecting its clayey nature. The sandy clay occurs beneath VES 14, 21, 22 and 29, where resistivity is greater than $100 \Omega \mathrm{m}$, along Profiles 4, 5, 6 and 7 respectively. The presence of clay is of great importance to landfill siting due to its attenuation and containment properties (Jones et. al. 1995, Comeau et. al. 1998). Clayey soils are suitable subsurface materials for landfill because they have low permeability. They serve as seal and hence would protect the underlying aquifer from being contaminated by the leachate dischargeable from decayed waste (Egwebe and Aigbogun, 2007).

The bedrock resistivity varies from 306 to $11343 \Omega \mathrm{m}$. indicating fractured/fresh bedrock. It is generally low at less than about $1000 \Omega \mathrm{m}$ in about $74 \%$ of the soundings, indicating fracturing and/or relatively deep weathering (Palacky et al., 1981; Hazell et al., 1992; Aina et al., 1996; Olayinka and Oyedele, 2001). Bedrock resistivity beneath the other sounding points represents fresh bedrock. Depth to the bedrock varies from 3.4 to $20.5 \mathrm{~m}$ with a minimum average of $6.7 \mathrm{~m}$ along Profile 7 and a maximum of $11.5 \mathrm{~m}$ along Profile 5 . The overburden is generally thin with an average thickness of about $9.0 \mathrm{~m}$.

Figure 5 and 6 show the variation of overburden thickness and depth to clay top, respectively, across the study area. Overburden thickness generally increases toward the southeast. Depth to clay top is about $14 \mathrm{~m}$ beneath VES 6 and VES 8 along Profile 2 reaching a maximum of about 20m beneath VES 21 at the southeast end of Profile 5. This reflects different degrees of weathering of the basement rock. Clay layer resistivity increases beyond $100 \Omega \mathrm{m}$ at the southeast end of Profiles 4 and 7 indicating sandy clay (Figure 7) while the thickness of the clayey layer increase toward the southeast end (Figure 8).

Results of 2D inversion of the resistivity data shows the resistivity distribution beneath the seven profiles across the study location and are presented in Figures 9 and 10. The resistivity of the overburden is generally less than $100 \Omega \mathrm{m}$, reflecting its clayey nature. The bedrock beneath Profile 1 is fractured at stations 12 and 14 while that beneath Profile 2 is fractured at stations 1-9 and 15-20. The conductive zones occurring in the latter may indicate intense fracturing. Profile 3 shows low resistivity overburden underlain by intensely weathered and fractured bedrock at stations 8-10, 15-17 and 21-26. The resistivity structure for Profile 4 shows resistivity values of $108-384 \Omega \mathrm{m}$ suggesting weathered outcrop at stations $11-14$. The bedrock is fractured beneath stations 5-7 and 13-17 while the conductive zone occurring at about $5 \mathrm{~m}$ depth beneath stations 14-16 may be due to intense fracturing. The fractures may serve as pathways for the leachate dischargeable within the landfill wastes.

Profiles 5 and 6 reveal clayey overburden with the bedrock intensely weathered beneath stations 8-15 and stations 12-16 respectively. The bedrock occurs at depths varying from 3 to $5 \mathrm{~m}$ at the northwest end of both profiles. Profile 7 shows clayey overburden with fractures occurring in the bedrock beneath stations 11-14 and 18-21 and the southeast end. The presence of bedrock fractures as revealed by the interpretation of the horizontal profiling 
data would make the site unsuitable for landfill purpose.

The physical measurements obtained from eleven hand dug wells located around the study area are presented in Table 1 while the groundwater flow pattern is shown in Figure 11. The water table is generally shallow, ranging from 2 to $6 \mathrm{~m}$ and may be rather close to the landfill base or fall within the landfill wastes. The landfill base should be a minimum of $1.5 \mathrm{~m}$ above groundwater level at all times (British Columbia, 2016). The direction of groundwater flow from the study area is southward suggesting that the southern population may be most vulnerable as the leachate dischargeable from the wastes leaks through the fractures beneath the landfill.

\section{Conclusions}

The results of geoelectrical sounding and horizontal profiling conducted at the site of the proposed landfill revealed clayey overburden capable of protecting groundwater in the underlying aquifer unit from contamination by the leachate dischargeable from the landfill wastes. However, the presence of bedrock fractures the proposed site may constitute pathways for leachate to contaminate groundwater in the underlying aquifer unit and pose substantial health risk to the host community. It can therefore be concluded that the study area is not a suitable location for siting landfill.

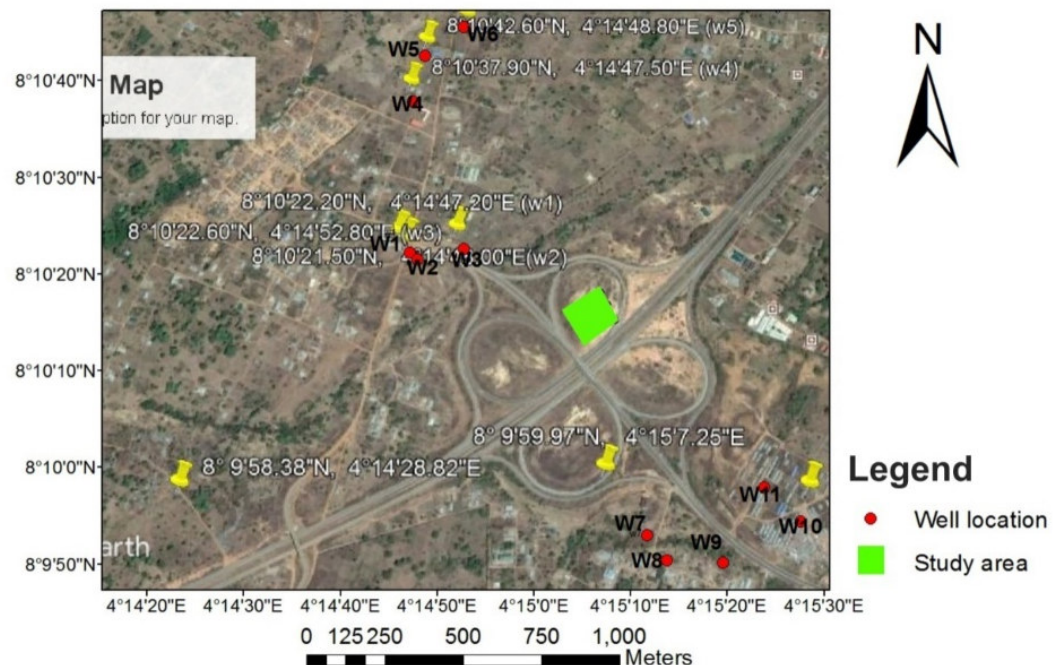

Figure 1. Location map of the proposed landfill site.

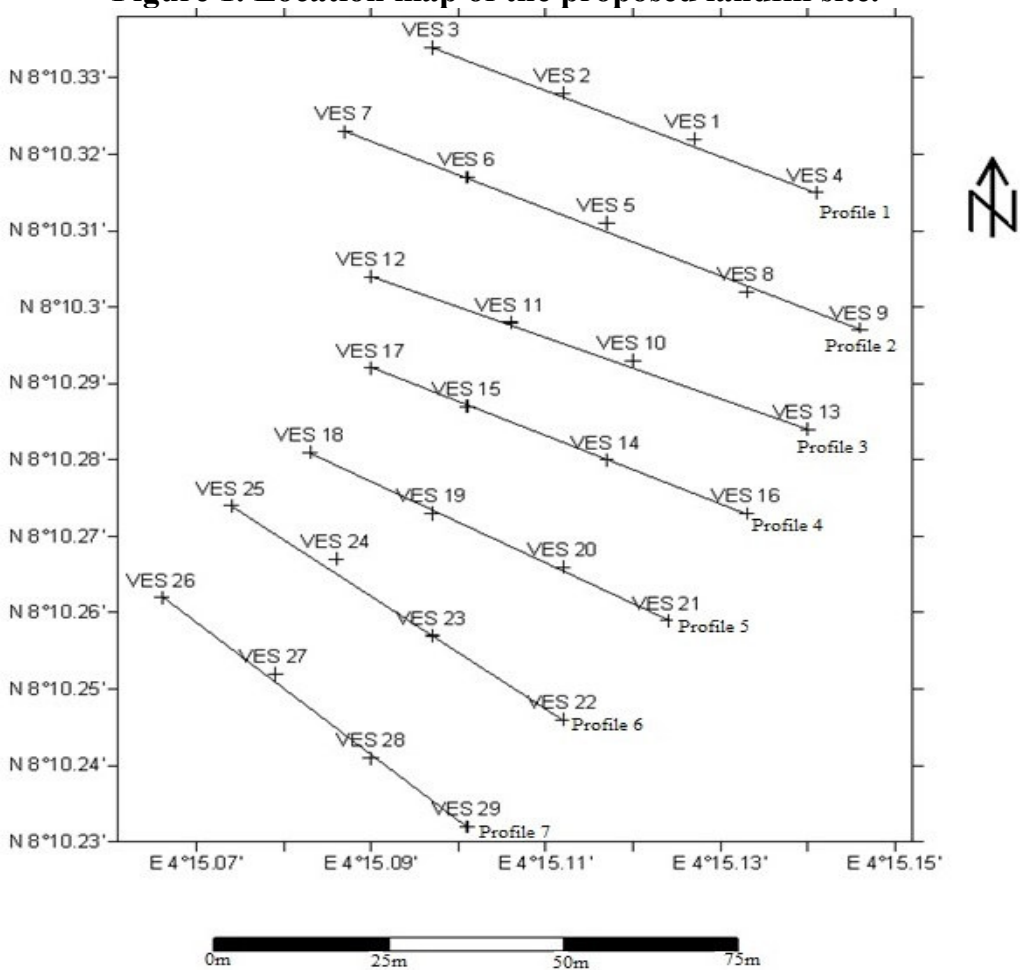

Figure 2. Field Layout for VES and Wenner profiling. 

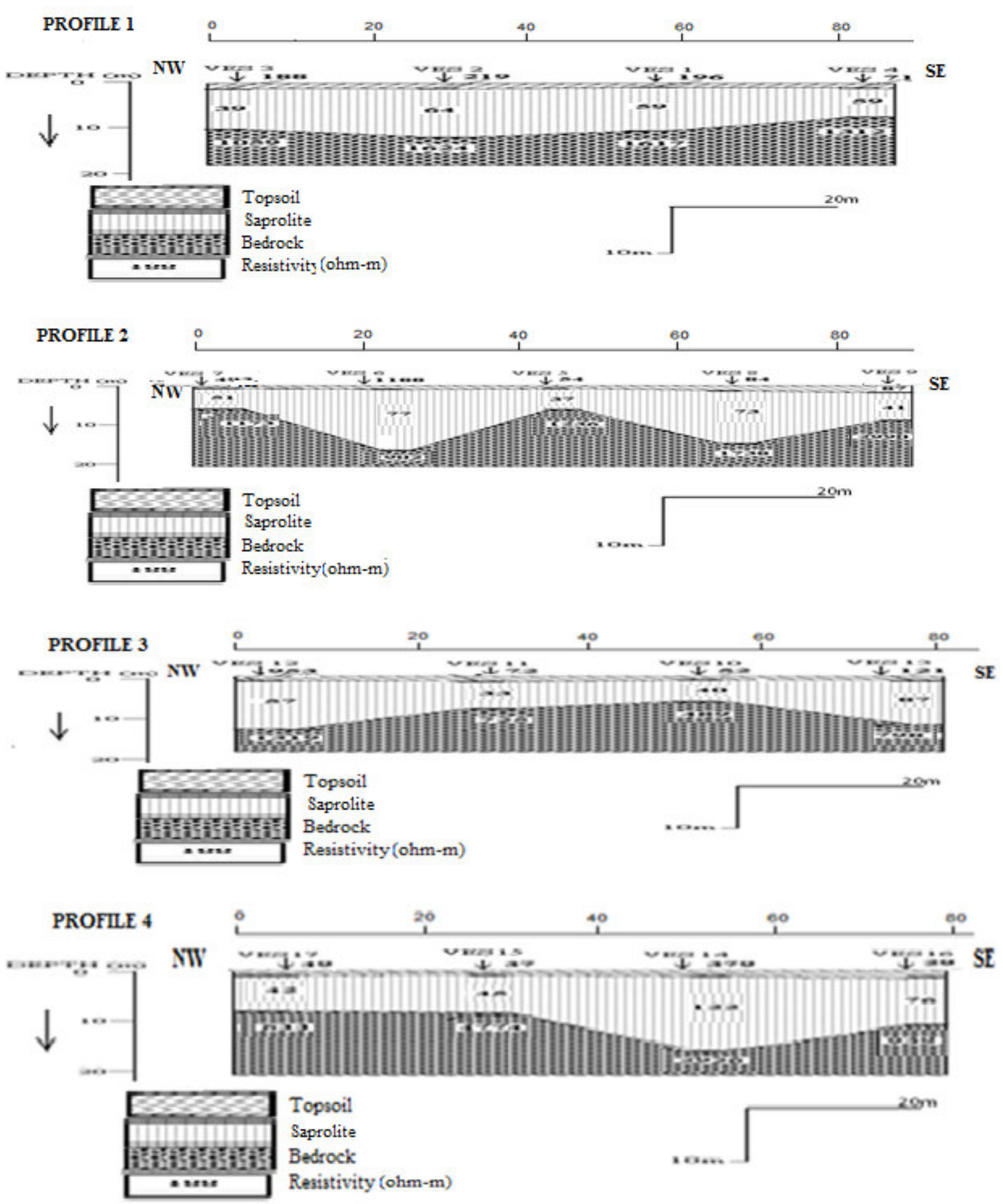

Figure 3. Geoelectric sections for Profiles 1-4 in the study area. 

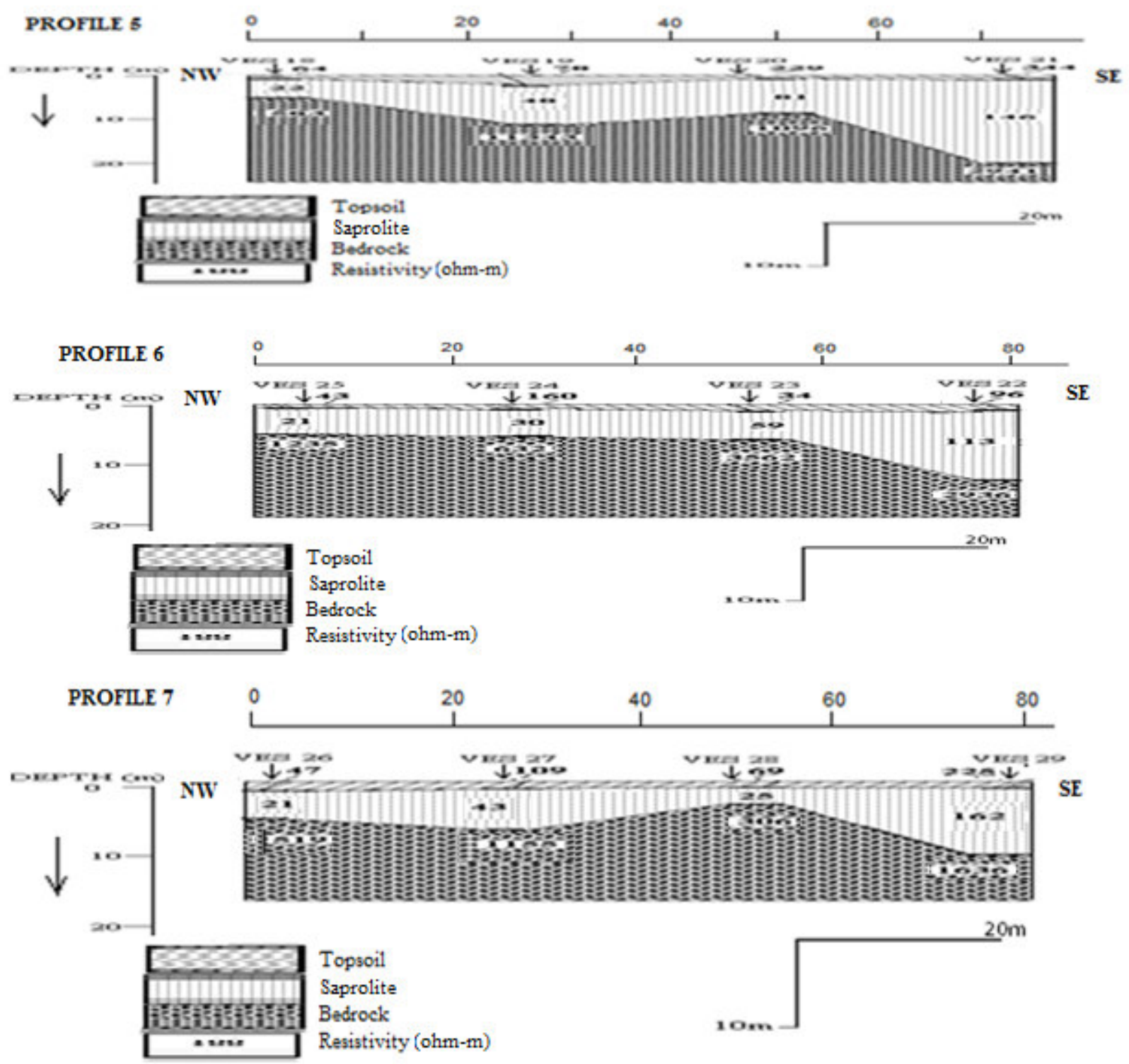

Figure 4. Geoelectric sections for Profiles 5-7 in the study area. 
N

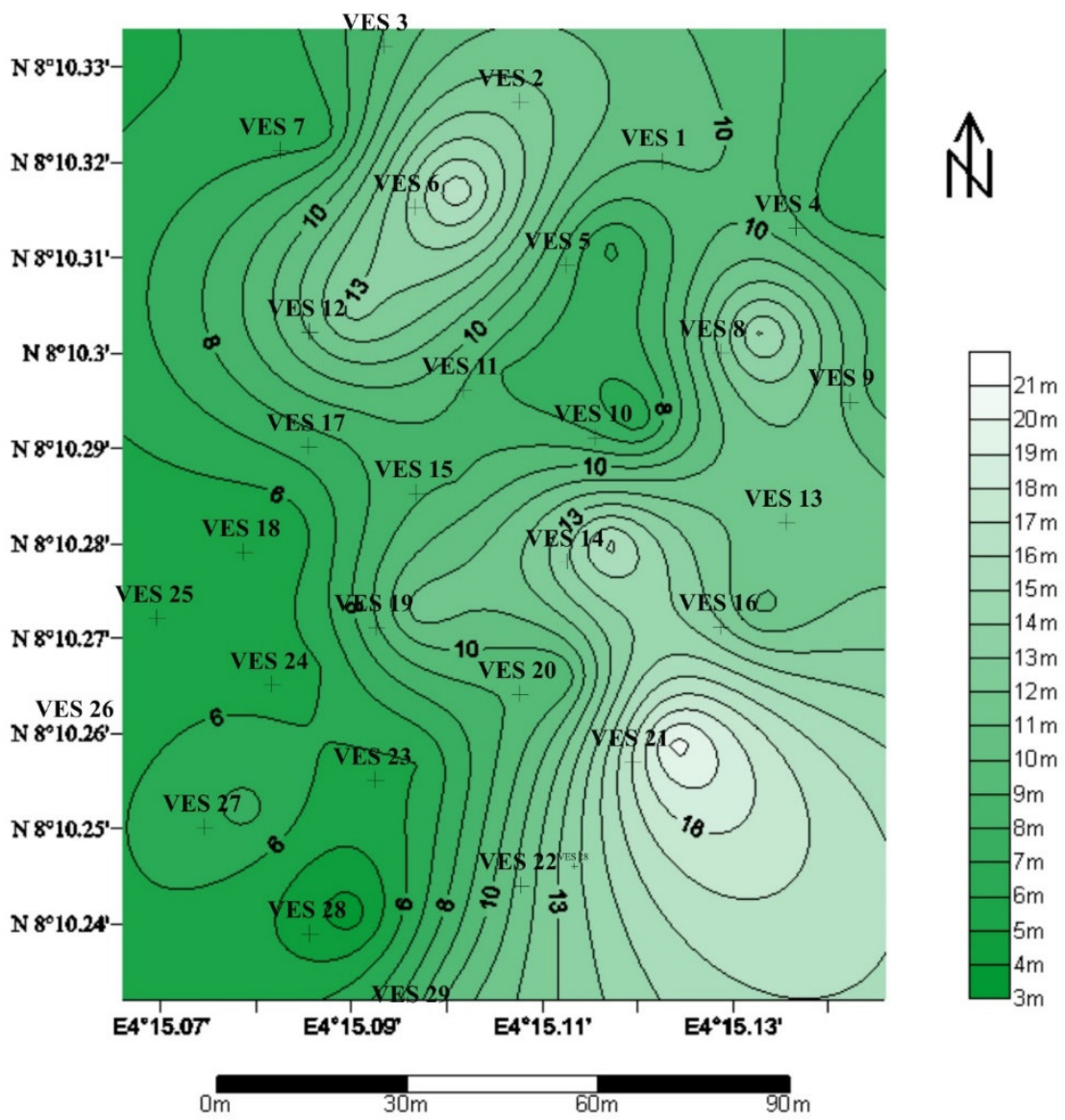

Figure 5. Overburden thickness map of the study area.

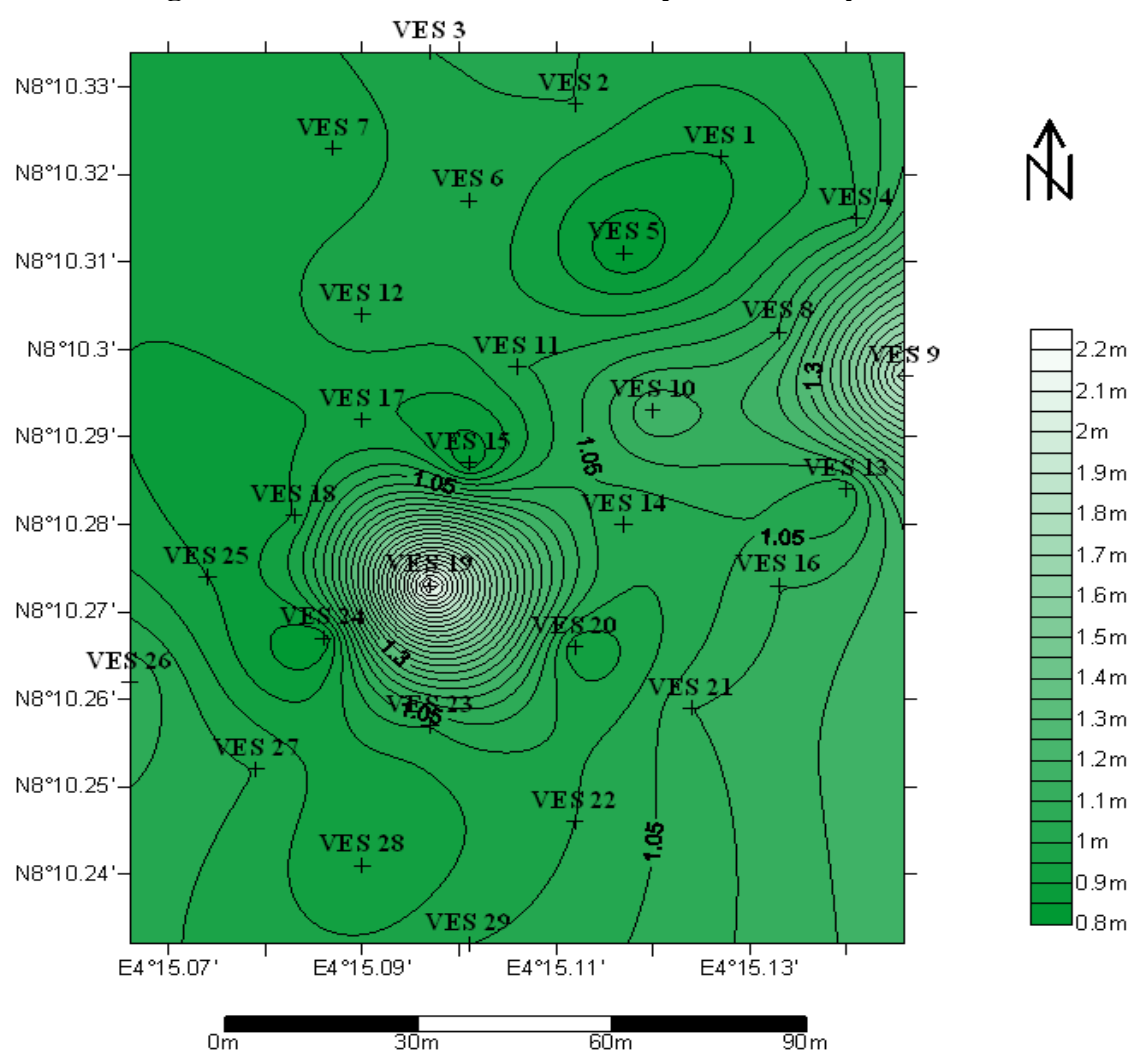

Figure 6. Depth to Clay top in the study area 


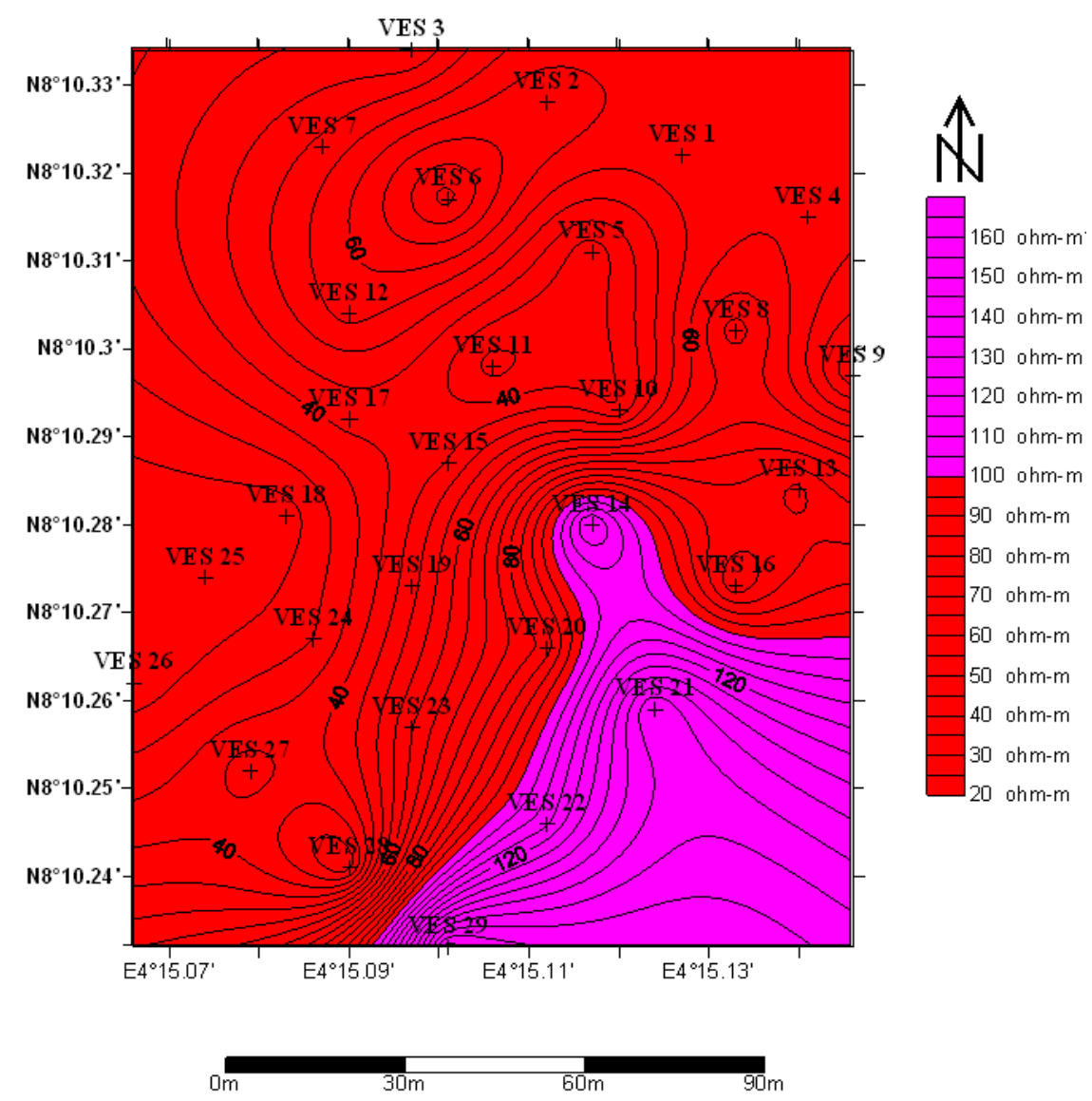

Figure 7. Clay layer resistivity map.

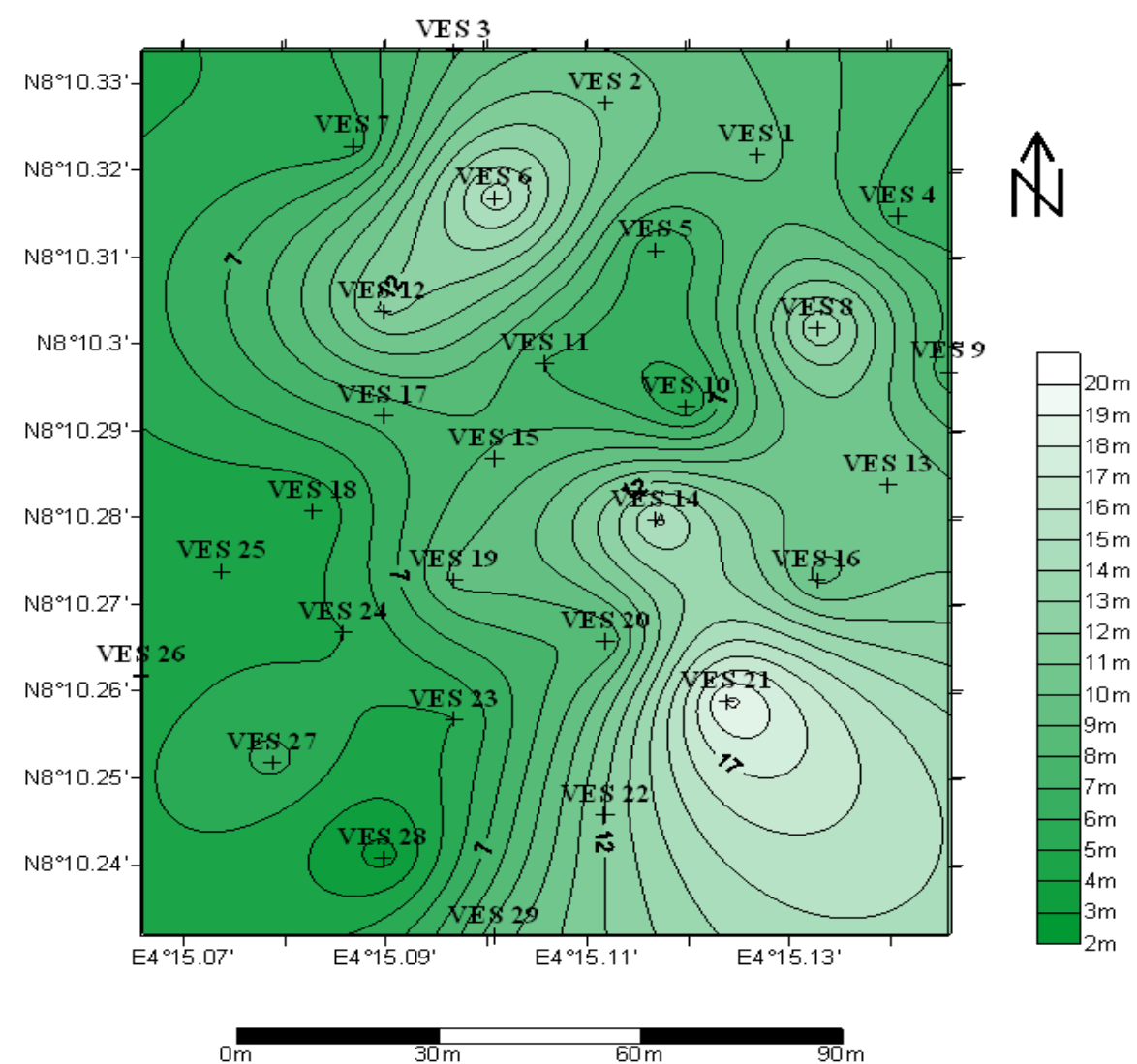

Figure 8. Clay layer thickness map. 
PROFILE1 (2-D Resistivity Structure)

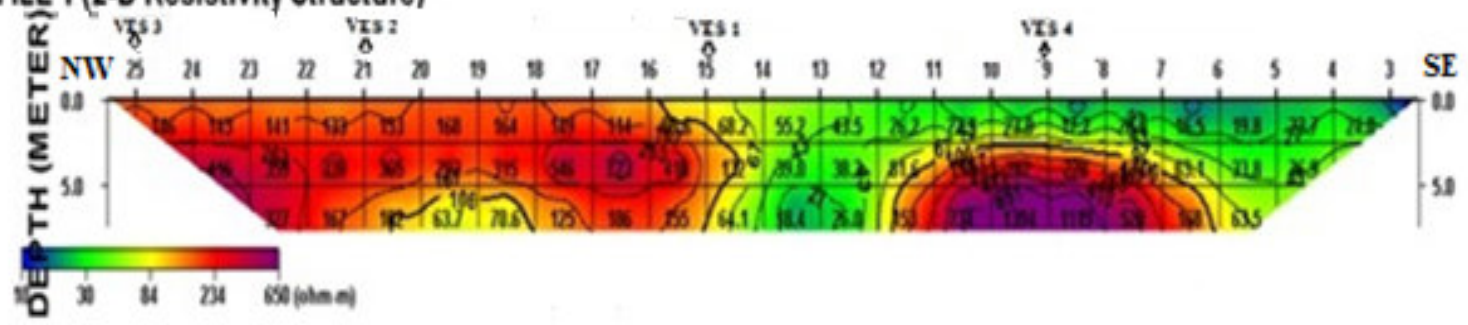

PROFILE 2 (2-0 Resistivity Structure)

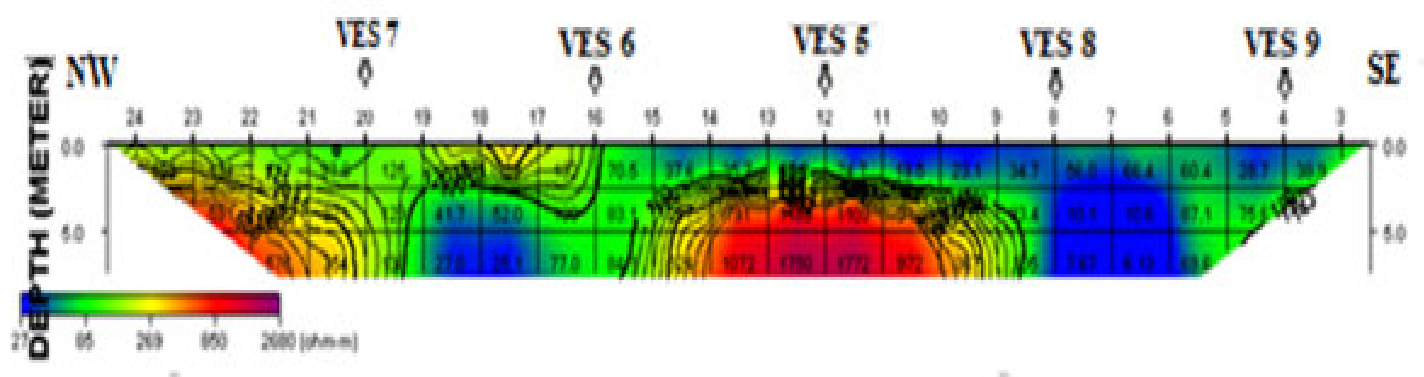

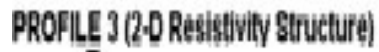

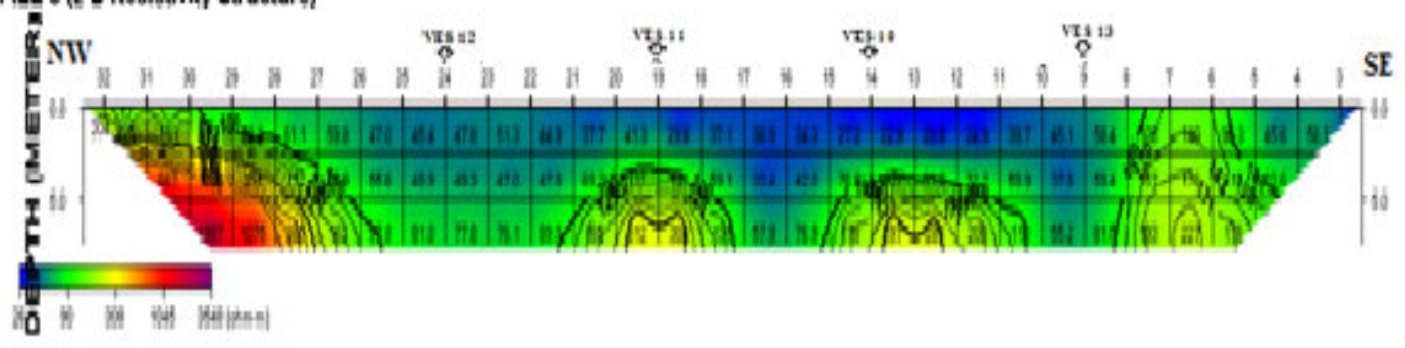

PROFILE 4 (2-D Resistivity structure)

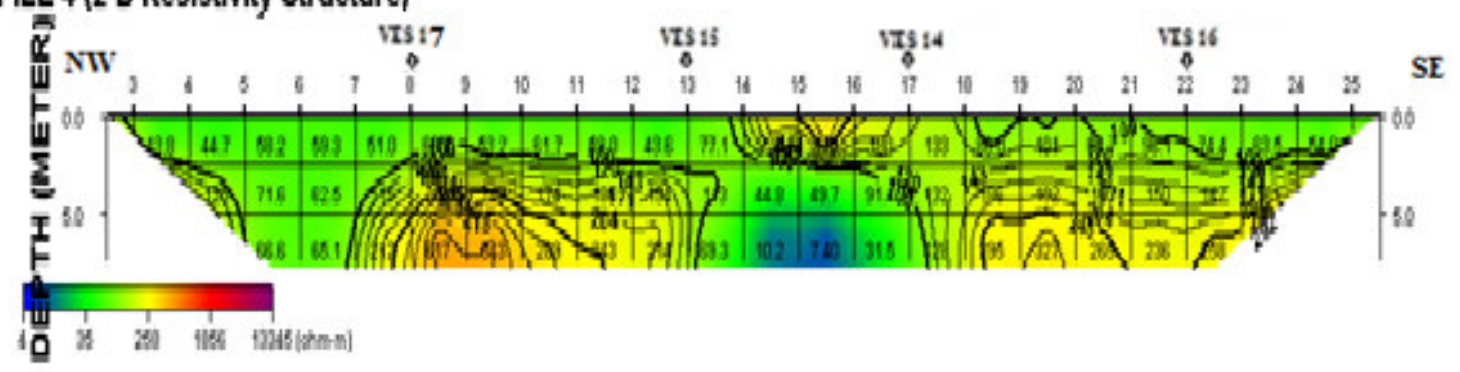

Figure 9. 2D Resistivity Structures for Profiles 1-4 in the study area. 


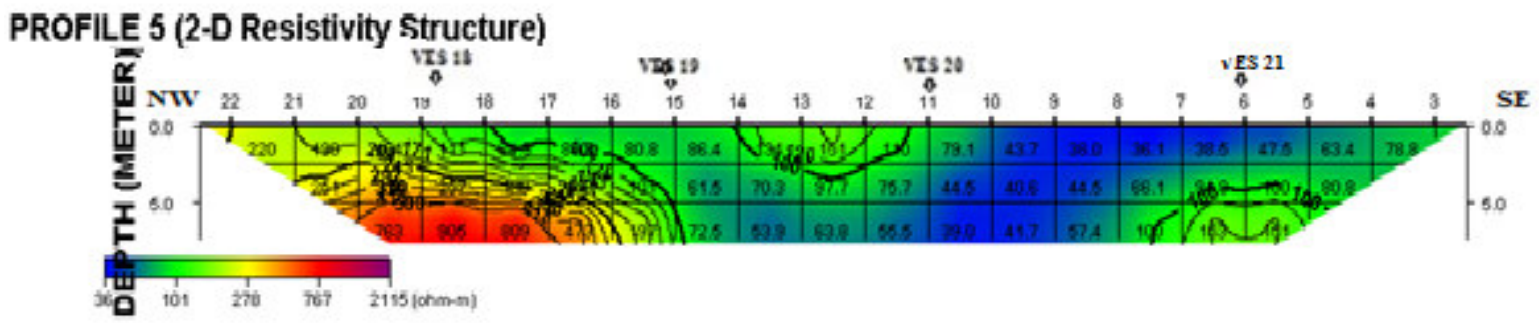

\section{PROFILE 6 (2-D Resistivily Structure)}
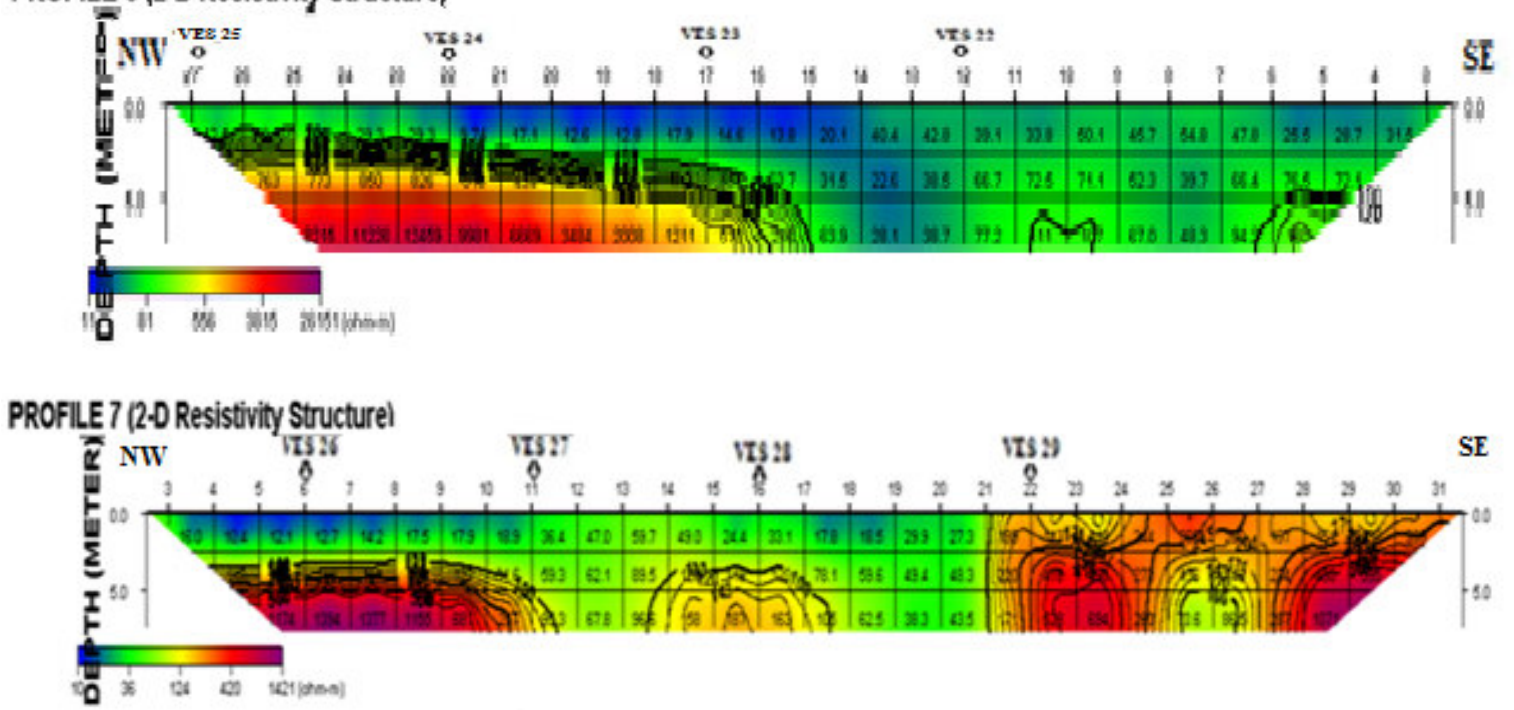

Figure 10. 2D Resistivity Structures for Profiles 5-7 in the study area.

Table 1: Physical measurements obtained from hand dug wells around the study location

\begin{tabular}{|c|c|c|c|c|}
\hline Well No. & $\begin{array}{l}\text { Elevation of Well } \\
\text { Location Above Sea } \\
\text { Level (m) }\end{array}$ & $\begin{array}{l}\text { Elevation of Well } \\
\text { bottom Above Sea } \\
\text { Level (m) }\end{array}$ & $\begin{array}{l}\text { Elevation of Water } \\
\text { Table Above Sea } \\
\text { Level (m) }\end{array}$ & $\begin{array}{l}\text { Depth to Water } \\
\text { Table (m) }\end{array}$ \\
\hline W1 & 341 & 332 & 335 & 6 \\
\hline W2 & 342 & 339 & 340 & 2 \\
\hline W3 & 336 & 332 & 334 & 2 \\
\hline W4 & 335 & 327 & 331 & 4 \\
\hline W5 & 329 & 324 & 327 & 2 \\
\hline W6 & 338 & 332 & 335 & 3 \\
\hline W7 & 335 & 331 & 332 & 3 \\
\hline W8 & 341 & 335 & 338 & 3 \\
\hline W9 & 339 & 336 & 337 & 2 \\
\hline W10 & 344 & 339 & 340 & 4 \\
\hline W11 & 347 & 341 & 343 & 4 \\
\hline
\end{tabular}




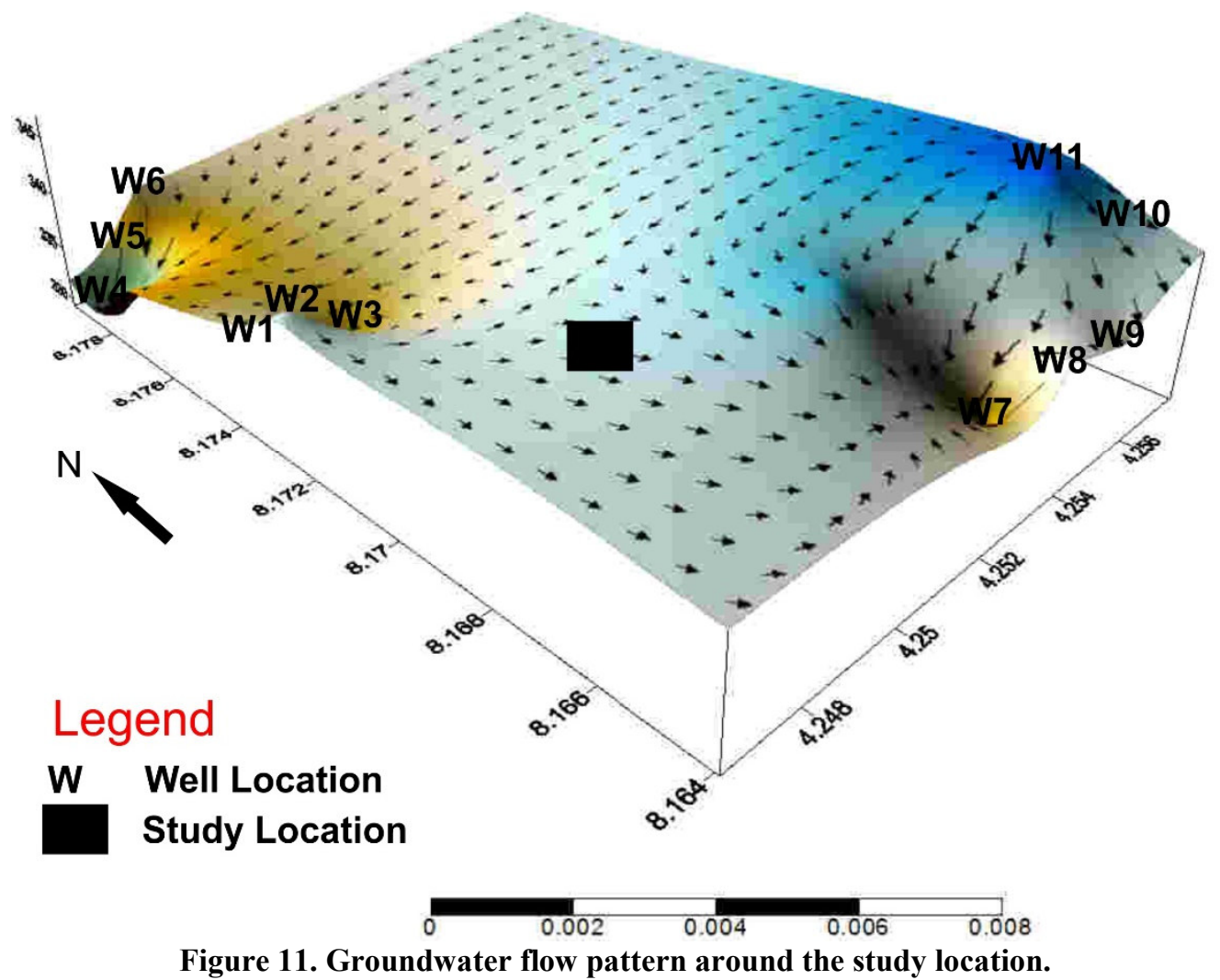

\section{References}

1. Abu-Hassanein,Z S; Benson,C H and Blotz,L R (1996). Electrical resistivity of Compacted clays, Journal of Geotechnical Engineering, 122(5), 397-406.

2. Adeyemi, G.O. and Oyediran, I.A. (2005). Engineering geological evaluation of a proposed landfill site at AbaKulodi, near Ibadan, southwestern Nigeria. Global Journal of Geological Sciences, 3.1: 25:33.

3. Al-Jarrah, O., \& Abu-Qdais, H. (2006). Municipal solid waste landfill siting using intelligent system. Waste management, 26(3), 299-306.

4. Benson, R.C., 1993. Geophysical Techniques for subsurface site characterization. In: D.E Daniel (ed). Geotechnical Practice for waste disposal, Chapman and Hall, London. pp 311-357.

5. British Columbia, 2016. Landfill Criteria for Municipal Solid Waste. Second Edition. BC Ministry of Environment. pp76.

6. Comeau, S., Chiasson, P., Massiers, M. and Caissie, M.A. (1998). Liner construction using tills composed of weakly cemented particles. Proceedings third international congress on Environmental geotechnics, Lisbon Portugal.

7. Dey, A. and Morrison, H.F., 1979 Resistivity modelling for arbitrarily shaped three-Dimensional structures: Geophysics, Vol. 44, pp. 753-780.

8. Edwards, L.S., 1977. A modified pseudosection for resistivity and IP. Geophysics 42, 1020-fractured crystalline-rock terrane. J. Appl. Geophys. 51, 21-41.

9. Egwebe, O (2003). Environmental geophysics: Site characterization of the Delta State Region of the Niger Delta by Electrical Resistivity Methods. Ph.D. Thesis, University of Benin, Benin City. pp306

10. Fejes, I.; Josa, E (1990). The Engineering Geophysical sounding Principles, Instrumentation, and Computerised Interpretation. In S.H.Ward (ed),Geotechnical and Environmental and Groundwater SEG. Publications. pp. 321-3.

11. Hamer, G. (2003). Solid waste treatment and disposal: effects on public health and environmental safety. Biotechnology Advances, 22(1), 71-79.

12. Hohnmann, G.W., 1982. Numerical modeling for electrical geophysical methods. Proc. Int. Symp. Appl. Geophs. Trop. Reg. Univ. d. Para. Belem. Brazil. P. 308-384.

13. Jones, R.M., Murray, E.J., Rix, D.W., and Humphrey, R.D., (1995). Selection of clays for use as landfill liners. Waste disposal by landfill-GREEN'93, Sarsby (ed.) Balkema, Rotterdam, 6p.

14. Lema, J. M., Mendez, R., \& Blazquez, R. (1988). Characteristics of landfill leachates and alternatives for their 
treatment: a review. Water, Air, and Soil Pollution, 40(3-4), 223-250.

15. Loke, M.H. (1999). A practical guide to 2D and 3D surveys. Electrical imaging surveys for environmental and engineering studies, Geotomo software, Malaysia, 8-10.

16. Olayinka, A.I. and Oyedele, A.A. (2001). Geoelectrical investigation of sites along the proposed Ibadan-Ilorin Dual carriageway. Jour. Min. and Geol. Vol. 37(2) pp. 163-175.

17. Rahaman, M.A. 1988. Recent advantages in the study of the basement complex Nigeria. In Oluyide, S.P., Mbonu W.C., Ogezi, A.E., Egbuniwe, I.C., Ajibade, A.C. and Umeji, A.C (ed.). Precambrian Geology of Nigeria, Geol. Surv. Nigeria, pp. 11-41.

18. Schmoll, O. (Ed.). (2006). Protecting Ground Water for Health: Managing the Quality of Drinking-water Sources. World Health Organization.

19. Scott, J., Beydoun, D., Amal, R., Low, G., and Cattle, J. (2005). Landfill management, leachate generation, and leach testing of solid wastes in Australia and overseas. Critical Reviews in Environmental Science and Technology, 35(3), 239-332.

20. Sharma, P.V. (1997). Environmental and Engineering Geophysics, Cambridge University Press, New York, USA, 207-237.

21. Steeples, D.W. (2001). Engineering and environmental geophysics at the millennium. Geophysics, 66, 31-35. 